

\section{LSA Cyclone Incinerator Development Program for May 1976}

Issued: July 16, 1976

\section{MONSANTO RESEARCH CORPORATION}

A Subsidiary of Monsanto Company

\section{mOUnD IABORATORY}

Miamisburg, Ohio

45342

operated for

\section{UNITED STATES ENERGY RESEARCH}

AND DEVELOPMENT ADMINISTRATION

U.S. Government Contract No. E-33-1-GEN-53 


\section{DISCLAIMER}

Portions of this document may be illegible in electronic image products. Images are produced from the best available original document. 


\section{DISTRIBUTION}

\section{Externa1}

J. A. Chacon, ERDA/DAO (2)

D. Davis, ERDA/ALO (2)

R. A. Wolfe, ERDA/DNFCP (2)

\section{Internal}

A. G. Barnett

R. K. Blauve1t

J. D. Braun

W. T. Cave

D. A. Edling

S. S. Freeman

K. V. Gilbert

E. W. Johnson

L. V. Jones

D. P. Ke11y

B. R. Kokenge

D. F. Luthy

J. R. McClain

D. L. Prosser

J. E. Todd

R. E. Vallée

H. L. Williams

Library (15)

Technical Publications 
MONTHLY PROGRESS REPORT

May 1 through May 31, 1976

During May, the major effort was directed toward installation of the Venturi scrubber in the offgas system which is expected to be complete by mid-June.

Some incineration runs were made to collect additional particulate data and the analysis was completed on the $\mathrm{NO}_{\mathrm{x}}$, $\mathrm{HCl}$, vinyl chloride and total hydrocarbon data from spot samples, collected earlier.

A. Venturi Scrubber Installation

Installation of a Venturi scrubber and auxiliary equipment was initiated on May 24, 1976. The Venturi scrubber was fabricated by Fisher-Klosterman. Inc., to remove $99 \%$ of the particulates from a gas stream characterized as follows:

1. Air flow 225 ACFM (actual cubic feet per minute) to 550 ACFM at $130^{\circ} \mathrm{F}$ saturated with moisture

2. Inlet gas 0.06 grains of particulates per actual cubic foot

3. Inlet particle size distribution (actual measured values from spray tank outlet)

$100 \%$ below 7 micrometers

$97 \%$ below 2.7 micrometers

$92 \%$ below 1.6 micrometers

$89 \%$ below 1.1 micrometers

$74 \%$ below 0.56 micrometers

$56 \%$ below 0.35 micrometers

4. Particle density $2.2 \mathrm{~g} / \mathrm{ml}$ (actual particle data)

The normal operating pressure drop in the scrubber will be 40-50 inches water gage.

Installation is presently on schedule and is expected to be complete by mid-June, 1976. 


\section{B. Particulate Data}

During the month, six incinerator runs were made before the shut-down for the Venturi scrubber installation. The results of these runs (two per feed type) substantiate previous data within statistical limits. The composition of the three types of feeds is defined in Table $I$. The efficiency of the spray tank in removing particulates generated by the three types of feed are summarized in Table II.

\section{TABLE I}

\section{COMPOSITION OF INCINERATOR FEEDS}

$\underline{\text { Type I }}^{(1)} \quad \underline{\text { Type II }}^{(1)} \underline{\text { Type III }}^{(1)}$

Paper

Plastics

PVC

Polyethylene

Polypropylene

Rubber

Cloth

Leather

Wood

Meta1
32

9
29
8
13
3
-
-
6

2

48

$\begin{array}{rr}23 & 1 \\ 9 & 6 \\ 2 & - \\ 3 & 26 \\ 61 & 6 \\ - & - \\ - & 7 \\ - & 6\end{array}$

(1) Weight \%

TABLE II

EFFICIENCY OF SPRAY TANK IN REMOVING PARTICULATES

Type I Feed

Type II Feed

Type III Feed

\section{A11 Particules \\ (\%)}

55.8

40.4

31.1

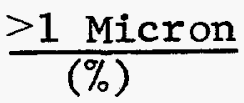

76.7

58.6

69.4 $\frac{<\text { Micron }}{(\%)}$

49.0

34.4

20.5 
Samples of flue gas were taken at the outlets of the incinerator chamber, the deluge tank and the roughing filter to determine their effectiveness in removing particulates. Table III lists the total particulate emissions at the three sample stations in relation to the total waste charge burned.

TABLE III

TOTAL PARTICULATE EMISSIONS

(av $\mathrm{g} / \mathrm{kg}$ Feed)

\begin{tabular}{|c|c|c|}
\hline $\begin{array}{c}\text { Combustion } \\
\text { Chamber }\end{array}$ & $\begin{array}{l}\text { Deluge } \\
\text { Tank }\end{array}$ & $\begin{array}{l}\text { Roughing } \\
\text { Filter }\end{array}$ \\
\hline 10.0 & 4.8 & 1.6 \\
\hline 7.9 & 4.7 & 1.0 \\
\hline 9.0 & 6.2 & 3.7 \\
\hline
\end{tabular}

C. Vinyl Chloride and Hydrocarbon Analysis of the Offgas Stream

Concentrations of vinyl chloride and total hydrocarbons present in the scrubber exit stream were determined with a portable gas chromatograph. The unit used was a Model 511, AID Portable Flame Ionization Detector (FID), Gas Chromatograph. By means of a hand pump, stack gas was drawn through a stainless steel probe into an automatic sampling valve. Total hydrocarbons were determined through a direct path to the FID. For the analysis of vinyl chloride (VC), however, chromatographic separation was necessary prior to introducing the sample into the flame ionization detector.

The results for nine different sample runs are given in Table IV. In the table, readings marked "greater than" ( ) are for values which exceeded the instrument range setting at the time of sampling.

On-1ine control instrumentation is used to continuous1y monitor combustible gas in the offgas. Results obtained with such equipment are consistent with the spot analyses given in Table IV. The value of $19,692 \mathrm{ppm}$ for run 283, 


\section{TABLE IV}

SUMMARY OF TOTAL HYDROCARBON (THC)

AND VINYL CHLORIDE (VC) RESULTS

\begin{tabular}{|c|c|c|}
\hline Run No. & $\mathrm{VC} \quad(\mathrm{ppm})$ & THC (ppm) \\
\hline $\begin{array}{l}277 \\
277 \\
277 \\
277 \\
277 \\
277\end{array}$ & $\begin{array}{r}>500 \\
200\end{array}$ & $\begin{array}{l}3,714 \\
4,500 \\
4,714 \\
5,143 \\
5,000 \\
4,214\end{array}$ \\
\hline $\begin{array}{l}278 \\
278\end{array}$ & $\begin{array}{r}1,040 \\
600\end{array}$ & \\
\hline $\begin{array}{l}279 \\
279 \\
279 \\
279 \\
279 \\
279 \\
279\end{array}$ & & $\begin{array}{l}65 \\
63 \\
47 \\
48 \\
52 \\
42 \\
62\end{array}$ \\
\hline $\begin{array}{l}280 \\
280\end{array}$ & $\begin{array}{r}>156 \\
200\end{array}$ & \\
\hline $\begin{array}{l}281 \\
281 \\
281\end{array}$ & $\begin{array}{l}40 \\
40 \\
24\end{array}$ & \\
\hline $\begin{array}{l}282 \\
282 \\
282 \\
282 \\
282 \\
282\end{array}$ & $\begin{array}{r}>77 \\
>308 \\
0 \\
0 \\
148 \\
>\quad 19\end{array}$ & \\
\hline $\begin{array}{l}283 \\
283 \\
283 \\
283 \\
283 \\
283\end{array}$ & $\begin{array}{r}19,692 \\
0 \\
0\end{array}$ & $\begin{array}{r}48 \\
51 \\
>381 \\
>762 \\
3,429 \\
3,429\end{array}$ \\
\hline $\begin{array}{l}284 \\
284 \\
284 \\
284 \\
284 \\
284\end{array}$ & 12 & $\begin{array}{r}>24 \\
>24 \\
4 \\
23 \\
22 \\
24\end{array}$ \\
\hline $\begin{array}{l}285 \\
285\end{array}$ & $\begin{array}{l}17 \\
14\end{array}$ & $\begin{array}{l}4 \\
3\end{array}$ \\
\hline
\end{tabular}


which was obtained by spot analysis, was confirmed by the line control instrumentation. Actually, such high peaks are instantaneous in nature and occur on $1 y$ occasionally during runs. Therefore, the magnitude of such peaks should not be construed as being representative of the vinyl chloride content of the offgas for a given run because lack of homogeneity of feed material and fluctuation in the incineration process have a significant influence on the size of the peaks.

Although the data are limited, oxidation of the vinyl chloride appears more difficult than oxidation of butyl rubber or the polyolefins.

\section{HCl Determination in Offgas Stream}

The HCl offgas analyses show anomalous results (Table V) which could be caused by sampling, analytical or process problems or a combination of the three. At this time, the possible causes of these anomalies have not been fully investigated.

TABLE V

MEASUREMENT OF REMOVAL OF HCI FROM OFFGAS

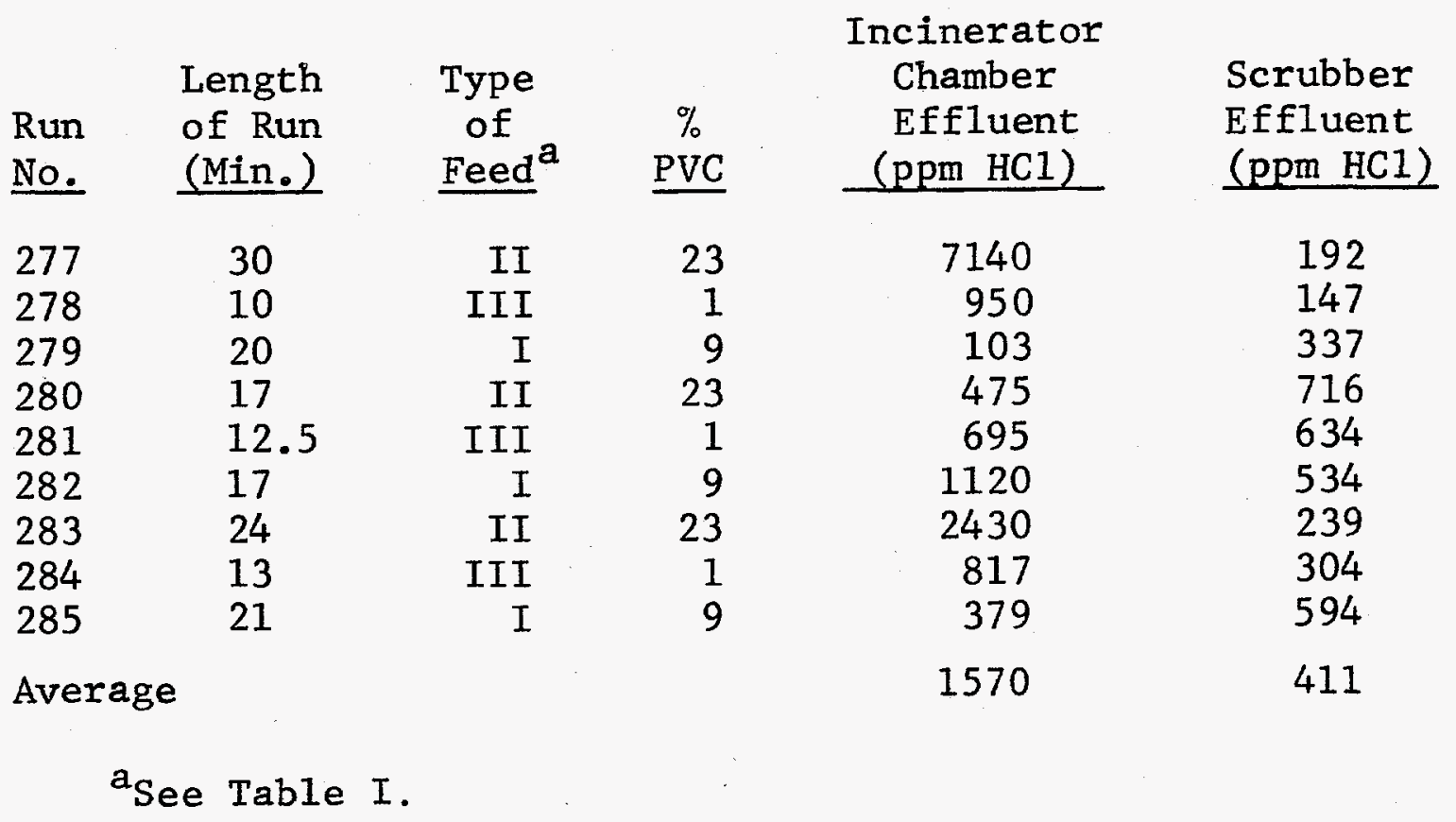


The levels of $\mathrm{HCl}$ found do not agree with the quantity of PVC burned. Also, in three cases, the scrubber effluent has a higher indicated concentration than the incinerator chamber effluent which further beclouds the validity of the data. The average value for the $\mathrm{HCl}$ removal efficiency appears to be about $74 \%$. The quantity of $\mathrm{Na}_{2} \mathrm{CO}_{3}$ used to neutralize the $\mathrm{HCl}$ to an acceptable $\mathrm{pH}$ level for different runs corroborates this average value. This value is much less than the values obtained earlier using Drager tubes. The earlier values were 10 to $20 \mathrm{ppm}$ for the scrubber effluent.

Further work is being done to determine the cause of these discrepancies. Findings will be reported as they become available.

E. $\mathrm{NO}_{\mathbf{x}}$ Analysis of the Offgas Stream

The analytical results on $\mathrm{NO}_{\mathrm{x}}$ spot sampling of ten incinerator runs are shown in Table VI. As can be seen, the average value and some of the individual results show a higher $\mathrm{NO}_{\mathrm{x}}$ content from the outlet of the scrubber than from the inlet. Examination of the sample timing as compared to offgas temperatures indicates that the scrubber outlet $\mathrm{NO}_{\mathrm{x}}$ concentration relates to offgas temperatures more than to scrubber efficiency. In some cases the scrubber outlet samples were taken at a later time and a higher temperature. Therefore, higher concentrations of $\mathrm{NO}_{\mathrm{x}}$ were present in the outlet sample than in the inlet. If the scrubber inlet and outlet samples were taken simultaneously, the outlet $\mathrm{NO}_{\mathrm{x}}$ concentrations would not be higher than the inlet but would fluctuate with the offgas temperature. To obtain more accurate data for the $\mathrm{NO}_{\mathrm{x}}$ content, instrumentation is being reviewed which will monitor the effluent to determine true concentration of $\mathrm{NO}_{\mathrm{x}}$ at any point during the run. 
TABLE VI

SUMMARY OF $\mathrm{NO}_{\mathrm{x}}$ ANALYSES

\begin{tabular}{|c|c|c|c|c|}
\hline \multirow[b]{2}{*}{ Run No. } & \multicolumn{2}{|c|}{ Incinerator Outlet } & \multicolumn{2}{|c|}{ Scrubber Outlet } \\
\hline & Sample No. & $\mathrm{NO}_{\mathrm{x}}$ Conc. & Sample No. & $\mathrm{NO}_{\mathrm{x}}$ Conc. \\
\hline & & (ppm) & & $(\mathrm{ppm})$ \\
\hline 276 & $\begin{array}{l}(3) \\
\text { (4) }\end{array}$ & $\begin{array}{l}17 \\
22\end{array}$ & $\begin{array}{l}(1) \\
(2)\end{array}$ & $\begin{array}{r}120 \\
34\end{array}$ \\
\hline 277 & $\begin{array}{l}(7) \\
(8)\end{array}$ & $\begin{array}{l}24 \\
30\end{array}$ & $\begin{array}{l}(5) \\
(6)\end{array}$ & $\begin{array}{l}25 \\
94\end{array}$ \\
\hline 278 & $\begin{array}{l}(11) \\
(12)\end{array}$ & $\begin{array}{l}12 \\
30\end{array}$ & $\begin{array}{r}(9) \\
(10)\end{array}$ & $\begin{array}{l}46 \\
6.6\end{array}$ \\
\hline 279 & $\begin{array}{l}(15) \\
(16)\end{array}$ & 169.4 & $\begin{array}{l}(13) \\
(14)\end{array}$ & $111^{5.9}$ \\
\hline 280 & $\begin{array}{l}(19) \\
(20)\end{array}$ & $\begin{array}{l}68 \\
47\end{array}$ & $\begin{array}{l}(17) \\
(18)\end{array}$ & $\begin{array}{l}29 \\
71\end{array}$ \\
\hline 281 & $\begin{array}{l}(23) \\
(24)\end{array}$ & $\begin{array}{l}49 \\
4.7\end{array}$ & $\begin{array}{l}(21) \\
(22)\end{array}$ & $\begin{array}{l}17 \\
30\end{array}$ \\
\hline 282 & $\begin{array}{l}(27) \\
(28)\end{array}$ & $\begin{array}{l}29 \\
22\end{array}$ & $\begin{array}{l}(25) \\
(26)\end{array}$ & $\begin{array}{l}44 \\
51\end{array}$ \\
\hline 283 & $\begin{array}{l}(31) \\
(32)\end{array}$ & $\begin{array}{l}54 \\
57\end{array}$ & $\begin{array}{l}(29) \\
(30)\end{array}$ & $\begin{array}{r}55 \\
160\end{array}$ \\
\hline 284 & $\begin{array}{l}(35) \\
(36)\end{array}$ & $\begin{array}{c}34 \\
8.8\end{array}$ & $\begin{array}{l}(33) \\
(34)\end{array}$ & $\begin{array}{r}109 \\
16\end{array}$ \\
\hline 285 & $\begin{array}{l}(39) \\
(40)\end{array}$ & $\begin{array}{r}159 \\
53\end{array}$ & $\begin{array}{l}(37) \\
(38)\end{array}$ & $\begin{array}{r}216 \\
73\end{array}$ \\
\hline & erage & 49.4 & & 65.7 \\
\hline
\end{tabular}




\section{F. Milestone Status for May 1976}

As described earlier in this report analysis of $\mathrm{NO}_{\mathbf{x}}, \mathrm{HCl}$, vinyl chloride and total hydrocarbons completes the analyses of the possible significant pollutants in the offgas stream. These data in addition to those reported in MLM-2326(LD) Milestone 3 (see Milestone Chart) will be marked complete, although further work on $\mathrm{NO}_{\mathbf{x}}, \mathrm{HCl}$, vinyl chloride, and total hydrocarbons will be necessary because of analysis problems and changes in equipment (addition of Venturi) mentioned earlier.

The utility requirements for the total incineration system will be included in the final report which will conclude the planned investigations for FY-1976. 


\section{CYCLONE INCINERATOR PROJECT}

FISCAL YEAR 1976

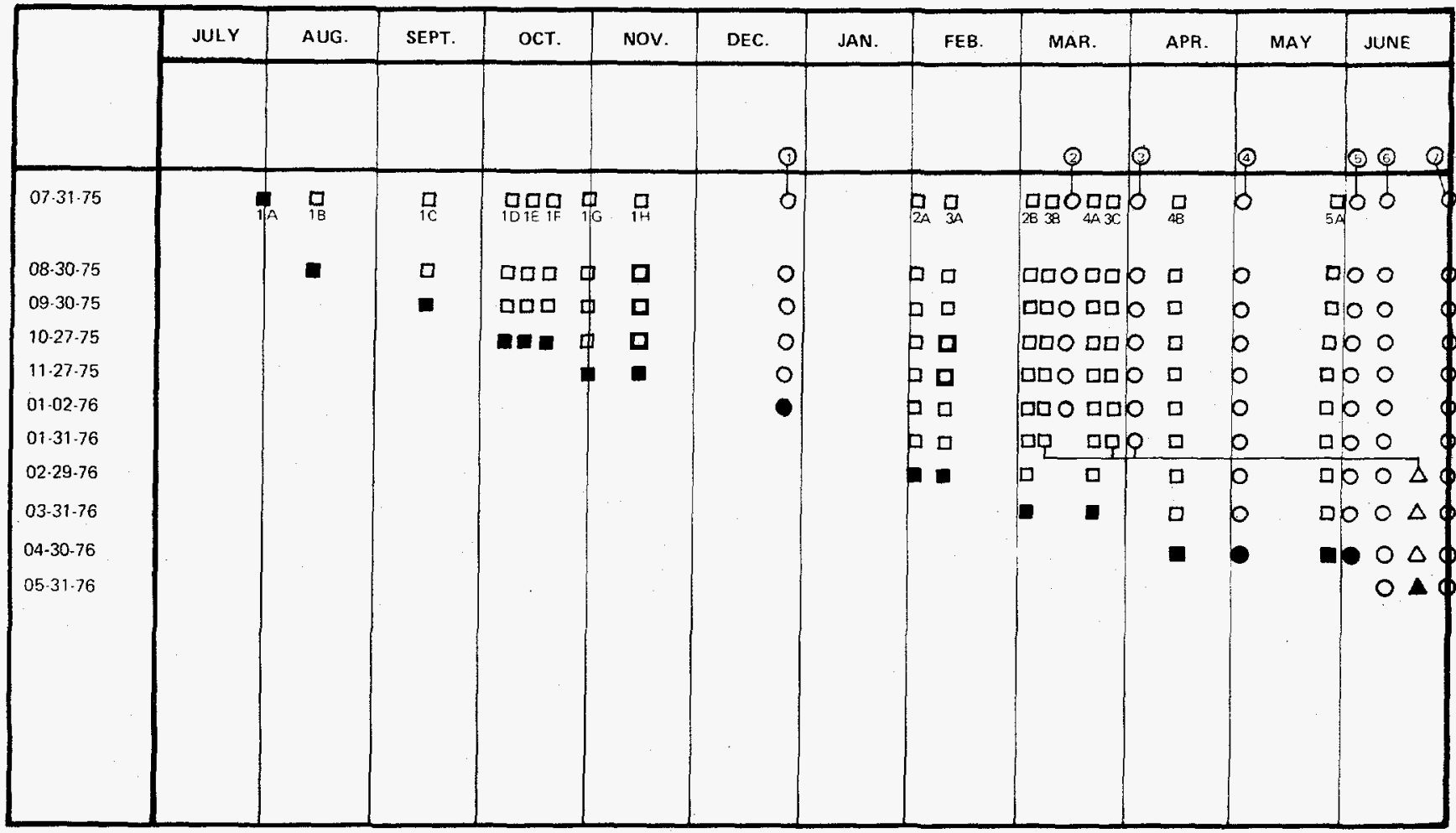

Legend: Milestone Target $O$, Revised Target $\Delta$, Terminated or Deferred X. Projected Activity Status $\square$, Actual Completed Activity $\mathbf{a}$, Completed Milestone

1. Instal1 Instrumentation and Optimize Incineration $(12 / 31 / 75)$

A. Installation of impactor (08/01/75)

B. Installation of new exhauster $(08 / 15 / 75)$

C. Installation of recycle water, chiller and flow meter (09/15/75)

D. Add wetting agent to all spray nozzles (10-10-75)

E. Optimize burning for reduction of particulate in offgas (10/15/75:

a. Vary air flow and oxygen content

b. Install oxygen stream to exhaust at chamber and test for usi on after burner

c. Final decision on use of cyclone, catalytic oxidizer or other type ofter burner for particulate reduction in exhaust stream $(05 / 15 / 76)$

F. Install and test more efficient roughing filter $(10 / 20 / 75)$

G. Determine effectiveness of spray tank and improve if necessary (10/30/75)

H. Install instrumentation for determining operating parameters (pressure drops, temperature profiles,

$\mathrm{O}_{2}$ and $\mathrm{CO}_{2}$ content, etc. (11/15/75)

2. Determine temperature and pressure profiles of system

A. Temperature profile of system $(02 / 01 / 76)$

a. Incinerator inlet air

a. Incinerator inlet air

b. Combustion chamber walls

c. Combustion chamber of

d. Spray catcher offgas

B. Pressure drops (03/01/76)

a. Incinerator chamber

b. Spray catcher

c. Mist eliminator

d. Roughing filter

e. Total systen

3. Gaseous Effluent Tests $(04 / 01 / 76)$

A. Particulate $(02 / 15 / 76)$

a. Size

b. Amount/distribution

B. Condensables $(03 / 10 / 76)$

a. Identify (water, organic, hydrocarbon, i.e., aldehydes, acids, alcohol, ketones, etc.)

C. Noncondensables $(03 / 25 / 76)$

a. Identify $\left(\mathrm{CO}_{2}, \mathrm{CO}\right.$, hydrocarbons, $\mathrm{HCN}, \mathrm{HCOH}, \mathrm{SO}_{2}, \mathrm{NO}_{x}, \mathrm{H}_{2}, \mathrm{O}_{2}, \mathrm{ClO}_{2}$, $\mathrm{HF}$, etc.

b. Amount

4. Identify and measure liquid and solfd waste generated (05/01/76)

A. Identify and measure total solid waste generated per unit volume of feed $(03 / 18 / 76)$

a. Liquid filter

c. Roughing fllter filter media

B. Identify and measure total 1 iquid waste generated per unit volume of feed $(04 / 15 / 76)$

a. Recycle water

5. Determine Efficiency of waste volume reduction $(06 / 01 / 76)$

A. Determine volume of ash per unit volume of feed $(06 / 01 / 76)$

6. Determine ut11ity requirements (06/15/76)

A. Total electric consumption

a. Exhauster

b. Water mist pump

c. Water chiller 